\title{
IPTEKS BAGI INOVASI DAN KREATIVITAS KAMPUS (IbIKK) BIBIT BUAH-BUAHAN LANGKA BALI
}

\author{
Jhon Hardy Purba ${ }^{1 *}$, Putu Suwardike ${ }^{1}$, I Dewa Nyoman Arta Jiwa ${ }^{2}$ \\ ${ }^{1}$ Fakultas Pertanian Universitas Panji Sakti \\ ${ }^{2}$ Fakultas Ekonomi Universitas Panji Sakti \\ Jalan Bisma No. 22, Singaraja-Bali 81117, Tlp. 0362-23588 \\ *Email: jhonhardy@yahoo.com
}

\begin{abstract}
ABSTRAK
Program IbIKK selama tiga tahun (2014-2016) bertujuan untuk: (1) meningkatkan kemandirian pendanaan kampus, (2) pengembangan budaya kewirausahaan, (3) menyediakan tempat magang/penelitian, (4) pelestarian plasma nutfah tanaman buah-buahan langka Bali, dan (5) penyediaan lapangan pekerjaan. Target luaran: (1) bibit dan tabulampot buah-buahan langka Bali, (2) jasa konsultasi/pelatihan, (3) Magang/penelitian mahasiswa, (4) wirausaha baru, (5) artikel yang dipublikasikan, (6) omzet, dan (7) pelestarian buah-buahan langka Bali. Mewujudkan tujuan tersebut dilakukan dengan mengoptimalkan sarana dan prasarana yang sudah ada dan penggunaan modal kerja yang berasal dari DRPM Ristekdikti dan Universitas Panji Sakti. Hasil yang dicapai yaitu: (1) Bibit buah-buahan langka Bali, (2) Peralatan agronomis untuk keperluan IbIKK dan praktikum mahasiwa,3) Sarana dan prasarana praktikum mahasiswa, (4) Tanaman buah langka Bali dalam Pot (Tabulampot), (5) Tempat penelitian mahasiswa. Proyeksi kedepan setelah kontrak IbIKK dengan DRPM Ristekdikti selesai pada akhir tahun 2016, program IbIKK menjadi unit usaha Fakultas Pertanian Universitas Panji Sakti.
\end{abstract}

Katakunci : IbIKK, bibit bermutu, tabulampot, buah langka, lokal Bali.

\section{Pendahuluan}

Indonesia sebagai salah satu mega biodiversity country, memiliki beraneka ragam jenis tumbuh-tumbuhan eksotis, terutama buah-buahan khas tropis yang tersebar di berbagai daerah di tanah air (Astirin, 2000; Suhartini, 2009). Pulau Bali yang hanya memiliki luas wilayah 563.286 $\mathrm{Ha}$ atau 0,29\% dari luas kepulauan Indonesiajuga dikenal memiliki beragam jenis buah-buahan khas tropis (lokal), seperti Salak Bali (Zalaca edulis Linn.), Jeruk Bali (Citrus grandis L. Osbeck), Jerungga (Citrus maxima Merr.), Jeruk Keprok Tejakula, Jeruk Kintamani, Anggur Bali (Alphonso delavalle Cv. Bali), beberapa jenis durian (Durio zibethinusMurr.), pisang (Musa sp.), mangga (Mangifera indica L.), wani (Mangifera caesiavar. Ngompen), sentul(Sandoricum koetjape Merr.), badung, kawista (Limonia acidissima), delima (Punica granatum L.), mundeh(Garcinia dulcis), klasem atau kaliasem (Eugenia polycepaia Mig.), pangi, kucacil (Schleichera oleosa Merr.), juwet (Eugenia cumini Merr.), kepuh, teep, boni (Antidesma nunius), kematau rukem (Flacuortia indica Merr.), lobi-lobi (Flacaurita inermis Roxb), katilampo atau batulampo (Elaeocarpus sp.), dan lain-lain. Saat ini, keberadaan beberapa jenis diantaranya mulai jarang dijumpai. Jenis buah-buahan lokal yang keberadaannya mulai jarang ditemukan di wilayah Provinsi Bali, antara lain: sentul atau kecapi (Sandoricum koetjape Merr.), gatep (Inocarpus edulis Forst), badung(Garcinia dulcis (Roxb.) Kurz.), mundeh (Garcinia dulcis), mangga amplemsari (Mangifera indica Linn. var. Legong), durian bestalaDurio zibethinus Murr. var. Bestala, kem atau rukem (Flacaurtia rukam Zoll \& Mor), buni (Antidesma nunius), juwet 
(Eugenia cumini Merr.), dan lain-lain. BPLH Bali (2011) menyebutkan beberapa diantara jenis tanaman tersebut keadaanya terancam. Menurut International Union for the Conservation of Nature and Natural Resources (IUCN), suatu tumbuhan dikatakan terancam (threatened) jika memenuhi tiga kategori yaitu kritis (Critically Endangered/CR), genting (Endangered/EN) atau rentan (Vulnerable/VU).

Mempertimbangkan pentingnya pelestarian jenis tanaman buah-buahan lokal, khususnya yang keadaannya mulai langka, maka Fakultas Pertanian Universitas Panji Sakti menaruh perhatian terhadap pelestarian buah-buahan tersebut melalui kegiatan pengembangan Iptek bibit tanaman buah-buahan langka. Disamping melalui kegiatan penelitian, upaya pelestarian tanaman buah-buahan langka juga dilakukan melalui pembinaan teknis pembuatan bibit yang baik dan kerjasama pemasaran dengan UD. Flora Dewata di Desa Temukus, Kecamatan Banjar dan CV.Karya Merta Wangi di Desa Suwug, Kecamatan Sawan, Kabupaten Buleleng. Pada tahun 2013 ini, Fakultas Pertanian Universitas Panji Sakti sedang menyiapkan bibit Sentul dan Badung sebanyak 500 batang untuk kegiatan rehabilitasi lahan di Kecamatan Nusa Penida, Kabupaten Klungkung dan 500 batang bibit Mangga Amplemsari, Durian Bestala dan Wani Ngompen untuk kegiatan penanaman di Kecamatan Sawan dan Busungbiu.

\section{Survey Pasar}

Survey pasar penting dilakukan sebelum memulai suatu usaha (Ibrahim, 2003). Saat ini terdapat lebih dari 35 penangkar bibit tanaman dan lebih dari 100 pedagang bibit di Provinsi Bali yang tersebar di 9 Kabupaten/Kota. Sebagian penangkar terfokus pada penangkaran tanaman hortikultura, seperti tanaman hias, buah-buahan dan biofarmaka, sedangkan sebagian lainnya terfokus pada penangkaran tanaman kehutanan atau kelompok kayu-kayuan. Usaha lebih berorientasi bisnis dan jarang dipadukan dengan upaya pelestarian, sehingga yang dipasarkan adalah bibit jenis tanaman yang populer atau digemari masyarakat.

Penjualan bibit di Bali dilakukan melalui beberapa cara, yaitu order melalui penangkar/pengusaha bibit, penjualan langsung melalui outlet bibit, dan penjualan melalui pedagang bibit keliling. Seorang pedagang pengecer bibit buah-buahan mampu menjual bibit antara 200-300 batang/bulan atau mencapai 20.000-30.000 batang untuk seluruh Bali/bulan. Volume penjualan bibit melalui order langsung ke penangkar lebih banyak lagi. Berdasarkan data Dinas Pertanian dan Peternakan Kabupaten Buleleng (2012), permintaan bibit tanaman buah-buahan dari berbagai daerah di Indonesia ke penangkar bibit di Kabupaten Buleleng rata-rata mencapai 809.000 batang per tahun. Sementara, kemampuan produksi 14 penangkar bibit hortikultura yang resmi terdaftar di Buleleng rata-rata baru mencapai 438.241 batang/tahunatau sekitar $54,17 \%$ dari total permintaan.Kekurangan bibit tersebut dipenuhi melalui pemasokan bibit dari luar Bali, khususnya Jawa Timur.

\section{Spesifikasi Produk}

Memperhatikan faktor-faktor penyebab rendahnya keberhasilan tumbuh tanaman pasca transplanting, maka bibit sebagai produk utama program IbIKK Bibit Buah-buahan Langka Bali dirancang memiliki spesifikasi dengan keunggulan bibit bermutu baik (Peraturan Menteri Pertanian No. 48, 2012).

Mutu bibit dimaksud mencakup mutu genetik, mutu fisik dan mutu fisiologis. Untuk menjamin mutu genetik bibit,dilakukan melalui pemilihan induk 
sumber benih atau mata tunas atau batang atas (entres) dengan cara yang sesuai dengan SOP pengadaan bibit bermutu baik. Untuk menjamin mutu fisik bibit, dilakukan melalui: a) Pemilihan biji, seedling (untuk batang bawah), mata tempel dan entres yang seragam dan sehat; b) Menerapkan SOP produksi bibit dengan baik; c) Mengatur jadwal pembuatan bibit agar pada saat penanaman kondisi bibit dalam keadaan baik; d) Membekali pekerja dengan pengetahuan dan ketrampilan pembuatan dan penanganan bibit yang benar.Untuk menjamin mutu fisiologis bibit, dilakukan melalui: a) Pemanenan buah/biji masak fisiologi atau memiliki kematangan yang cukup dan penanganan benih dengan baik; b) Menerapkan SOP produksi bibit dengan baik; c) Membekali pekerja dengan pengetahuan dan ketrampilan pembuatan bibit yang benar; d) Bibit lebih tahan cekaman kekeringan yang dihasilkan melalui aplikasi mikroorganisme (agens hayati) jamur dari genus Trichoderma dan Bakteri dari genus Bacillus.

\section{Kaitan Produk dengan Temuan dan HKI Perguruan Tinggi}

Program IbIKK ini terlaksana sebab didukung beberapa hal yang berhubungan dengan bidang yang dikelola. Ada 2 (dua) usaha penangkar bibit yang selama ini telah dibantu dan dibina oleh Fakultas Pertanian Universitas Panji Sakti, yaitu UD. Flora Dewata dan CV. Karya Merta Wangi. Tim Fakultas Pertanian Unipas memberikan pendampingan teknis produksi bibit dan kerjasama pemasaran dengan kedua perusahaan tersebut.

Keunggulan komparatif dari produk IbIKK ini adalah: (a) dihasilkan bibit bermutu dan lebih tahan cekaman kekeringan dari jenis buah-buahan yang tergolong langka di Bali; (b) dihasilkan jasa konsultasi teknik produksi bibit tanaman buah-buahan langka, sekaligus media edukasi bagi siswa, mahasiswa maupun masyarakat umum, dan (c) publikasi artikel tentang IbIKK buahbuahan langka Bali pada jurnal nasional.

\section{Dampak Sosial Ekonomi IbIKK}

IbIKK Bibit Buah-buahan Langka Bali memberikan dampak dan manfaat positif bagi perguruan tinggi (Universitas Panji Sakti), masyarakat, daerah maupun secara nasional.

\section{Target Luaran}

Dengan mempertimbangkan ketersediaan bahan baku, kapasitas produksi, lamanya waktu proses produksi, kemampuan manajerial, kemampuan promosi dan pangsa pasar yang ada, ketersediaan SDM, fasilitas yang ada, dan kemampuan finansial yang tersedia, maka target luaran IbIKK pada tahun III ditetapkan seperti tercantum pada Tabel 1.

Target-target luaran merupakan bagian tak terpisahkan dari jadwal kerja tahunan IbIKK Bibit Buah-buahan Langka Bali. Selanjutnya, untuk menghasilkan produk di atas, maka diterapkan berbagai pilihan Iptek yang secara skematis pada Gambar1.

Tabel 1. Target Luaran IbIKK Buah-buahan Langka Bali pada Tahun III

\begin{tabular}{rlc}
\hline No. & \multicolumn{1}{c}{ Jenis Luaran } & Terget Luaran Tahun III \\
\hline 1. & Bibit (batang) & 41.200 \\
2. & Tabulampot (pot) & 300 \\
3. & Jasa konsultasi usaha/pelatihan & 6 \\
4. & Magang/penelitian mahasiswa & 5 \\
5. & Wirausaha baru & 4 \\
6. & Artikel Publikasi (judul) & 1 \\
\hline
\end{tabular}


e-ISSN : 2622-4690

Abditani : Jurnal Pengabdian Masyarakat 2 (2) 79-86

p-ISSN : 2622-4682

\section{Metode Pelaksanaan}

\section{Bahan Baku}

Bahan baku yang digunakan meliputi: benih, biji untuk batang bawah (understem), mata tempel, entres, media pesemaian, media bibit, agens hayati dan sarana produksi (saprodi). Spesifikasi bahan baku yang dibutuhkan untuk produksi bibityaitu ukuran relatif seragam, masak fisiologis/cukup masak, sehat dan tidak cacat, kadar air cukup (sesuai tipe benih), dan berasal dari sumber tegakan teridentifikasi.

Mengingat bibit yang diproduksi merupakan buah-buahan langka, maka ketersediaan bahanbaku terutama benih, mata tempel dan entres tentulah sangat terbatas. Untuk itu, timpelaksana IbIKK telah mengatur pola pengelolaan bahan baku secara cermat.

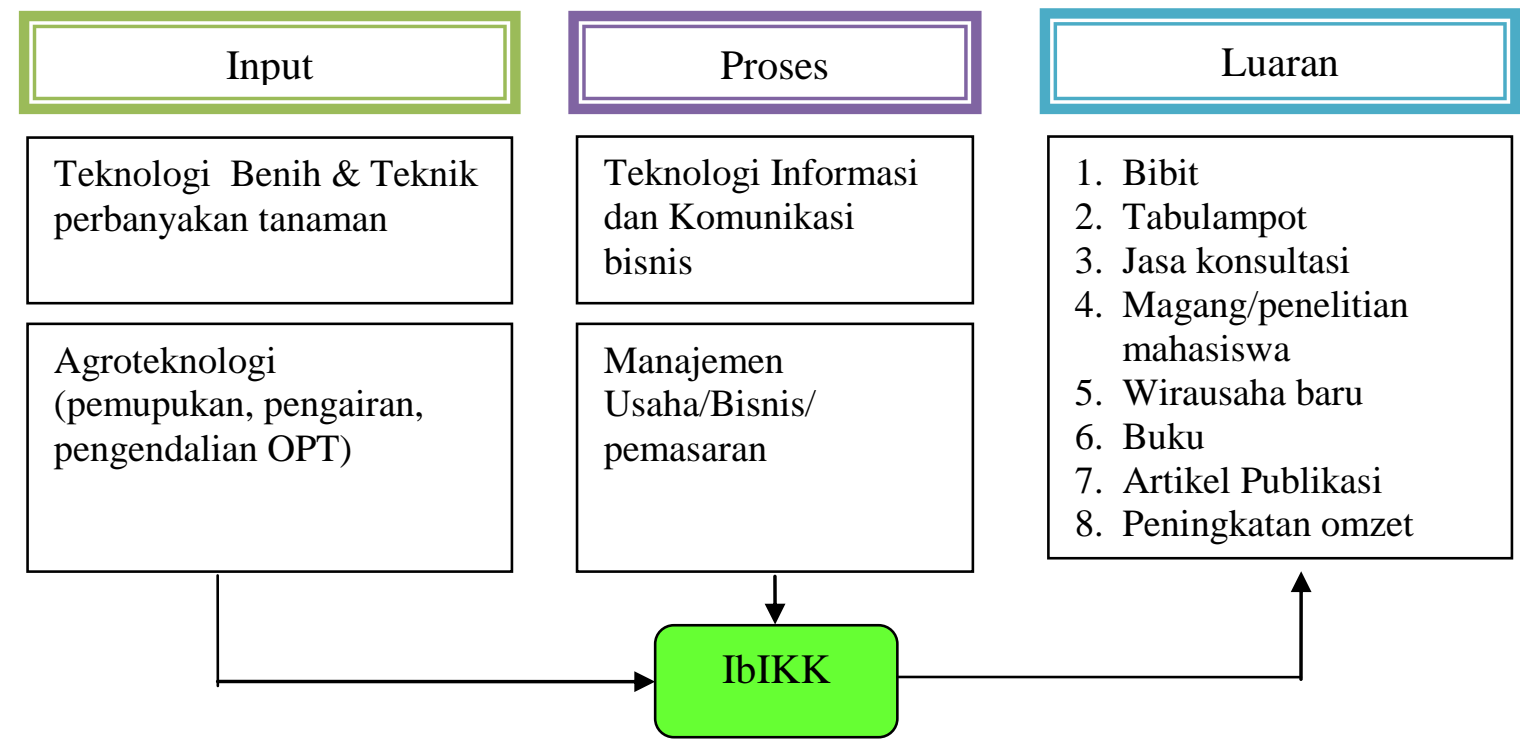

Gambar1. Pilihan iptek dan proses untuk menghasilkan luaran IbIKK Bibit Buah-buahanLangka Bali

\section{Proses Produksi}

Untuk menjamin mutu produk,proses produksi bibit hasil perbanyakan generatif diawasi oleh staf quality control. Sedangkan untuk bibit hasil okulasi dan grafting, disamping diawasi oleh staf quality control, juga dibawah pengawasan BPSP Provinsi Bali. Lama waktu yang dibutuhkan untuk menghasilkan bibit asal biji, bibit asal okulasi/grafting dan tabulampot berbeda-beda. Proses pembuatan bibit asal biji sampai dengan siap dipasarkan perlu waktu sekitar 6 bulan, namun pemberian sodium nitrophenolate growth regulator dapat mempersingkat dormansi biji (Purba, et al., 2019). Untuk bibit asal okulasi/grafting sekitar 1 (satu) tahun, dan untuk tabulampot minimal 1 tahun sejak bibit ditanam dalam pot.

\section{Pemasaran}

Perkiraan luasan pasar potensial penerima produk IbIKK Bibit Buah-buahan Langka Bali adalah sebagai berikut:a) Instansi pemerintah/swasta (50\%); b) Penangkar/Pengusaha Bibit di Provinsi Bali (kemitraan) (30\%);c) Outlet/Showroom (10\%); d) Perorangan (10\%). Salah satu kegiatan pemasaran kepada pembeli perorangan disajikan pada gambar 2 . Untuk memasyarakatkan informasi kegiatan usaha 
dan produk IbIKK ini ditempuh dengan beberapa cara, yaitu: 1) Publikasi melalui media elektronik berupa media sosialdi internet, radio, papan nama, tabloid; 2) Selebaran, brosur, leaflet dan poster; 3) Mengembangkan pola kemitraan dengan penangkar-penangkar bibit dan pedagang bibit di seluruh Bali; 4) Mengembangkan kerjasama pengembangan tanaman buahbuahan langka Bali dengan Dinas Pertanian Provinsi Bali, Dinas yang membidangi pertanian di tingkat kabupaten se Provinsi Bali dan Badan/Kantor yang membidangi kehutanan dan lingkungan hidup kabupaten se Provinsi Bali, dan BPDAS Unda Anyar; 5) Pameran-pameran pertanian.

\section{Sumberdaya Manusia}

Pelaksanaan program IbIKK Bibit Buah-buahan Langka Bali dukung oleh sumberdaya manusia (SDM) yang memiliki latar belakang pendidikan dan pengalaman relevan dengan usaha yang dikembangkan.

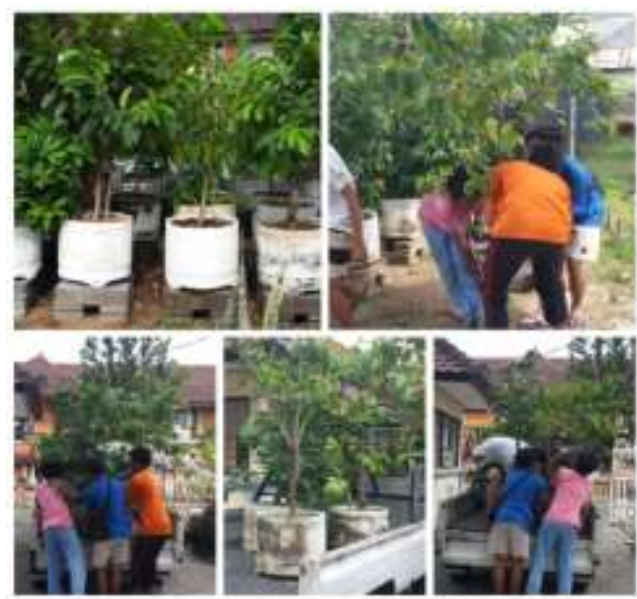

Gambar 2. Pemasaran tabulampot

\section{Fasilitas}

Lokasi kantor IbIKK dan showroom produk IbIKK terletak di Jl. Bisma No. 22 Singaraja. Sedangkan aktivitas produksi bibit difokuskan di Laboratorium dan Kebun Percobaan Agroteknologi Fakultas
Pertanian Unipas seperti tersaji pada gambar 3 .

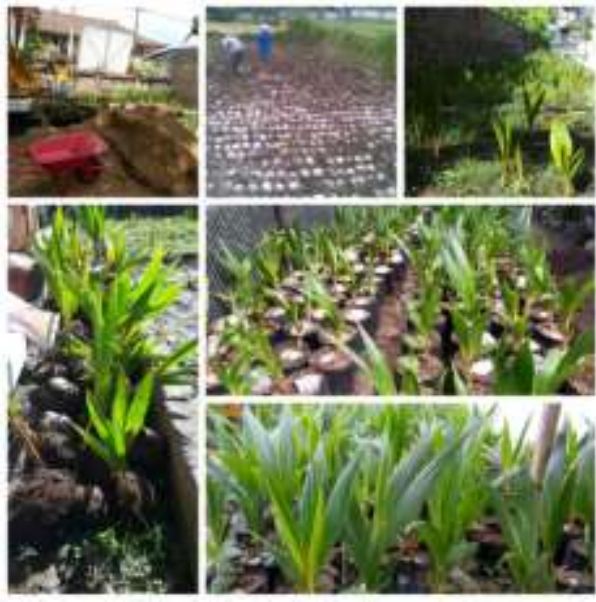

Gambar 3. Pembibitan Kelapa gading

\section{Hasil yang Dicapai}

Pembuatan bibit buah-buahan langka Bali merupakan usaha dan/atau kegiatan yang telah dirintis sejak beberapa tahun oleh Fakultas Pertanian Universitas Panji Sakti melalui UPT. Pembibitan tanaman. Oleh karena itu, sampai dengan jelang akhir tahun 2016 disamping telah memproduksi bibit juga telah mampu menjual/memasarkan bibit kepada masyarakat. Hasil yang telah dicapai sampai dengan jelang akhir tahun 2016 adalah sebagai berikut.

1. Koordinasi internal tim pelaksana, dengan pimpinan fakultas dan universitas

2. Pemeliharaan dan Perluasan Rumah Paranet/Agronet (rumah bibit) sebagai showroom bibit. Rumah paranet/agronet telah dibangun pada pelaksanaan IbIKK Bibit buah-buahan langka Bali tahun 2014 (tahun I). Pada tahun 2015, 2016 dilakukan pemeliharaan rumah paranet/agronet dan perluasan agronet seperti disajikan pada gambar 4.

3. Penyediaan Peralatan Agronomis dan Penunjang Usaha 
Untuk keperluan agronomis telah dilakukan juga pengadaan peralatan agronomis untuk keperluan IbIKK dan kegiatan praktikum mahasiwa seperti Lux meter, soil tester, soil survey SS 4 in 1, Altimeter, $\mathrm{C}$ meter, Digital calipper, moisture meter, timbangan digital, wireless pointer, kamera digital, Digital Multimeter BEST 9205A Multitester VOM AC DC, Refractometer Protein, CO Carbon Monoxide Gas Detector Digital, Wireless Weather Station Temperature, Humidity, Clock \& Weather Forecast, Mini Microscope 160-200x zoom with LED, Gorillapod Large - Flexible Tripod, Mini LED Projector, ORP + PH + Thermometer 3 in 1, gerobak sorong, dll.

4. Pembuatan dan Pemasaran Bibit Pembuatan bibit hingga jelang akhir tahun 2016 telah mencapai 41.200 batang dan 200 tanaman dalam pot (tabulampot). Sebagian bibit tersebut telah dipasarkan ke berbagai lokasi/daerah.

5. Penyediaan Jasa Tim Pelaksana IbIKK Penyediaan Jasa Tim Pelaksana IbIKK untuk bidang konsultansi di bidang pertanian secara umum untuk 3 kegiatan pada bidang pertanian dan lingkungan hidup.

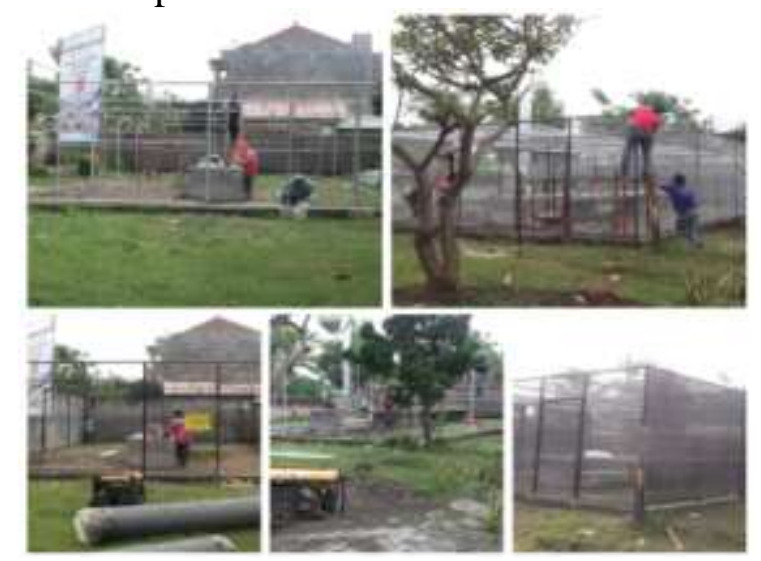

Gambar 4. Pembuatan rumah agronet
Sebagaian besar program dan kegiatan yang direncanakan pada tahun 2016 telah dan sedang dalam proses realisasi. Pembuatan bibit, tabulampot dan kegiatan pengelolaan usaha lainnya dilakukan secara kontinu. Dalam perjalanan pengelolaan usaha, tantangan utama yang dihadapi adalahsulitnya mendapatkan bahan tanam (benih/bibit) buah-buahan langka Bali, dan pemasaran produk juga cukup sulit karena belum banyak masyarakat mengenal manfaat buah-buahan tersebut. Dengan dukungan berbagai pihak, terutama Pemerintah Provinsi Bali dengan diberlakukannya Perda tentang Buahbuahan Lokal dan juga dukungan Pemerintah Kabupaten Buleleng melalui kebijakan pengembangan buah-buahan unggulan lokal Buleleng, terutama yang sudah cukup langka seperti mangga Amplemsari dan Durian Bestala, maka secara perlahan usaha bibit buah-buahan langka Bali mulai berkembang sesuai harapan (Perda Bali No. 16, 2009).

\section{Pembahasan}

Program IbIKK sangat banyak manfaatnya, antara lain sebagai wadah penerapan teori ilmu di lapang dan sebaliknya, pengalaman empiris di lapang menambah wawasan pengetahuan teori ilmu.Permasalahan yang nyata dialami oleh penangkaran bibit jeruk di Kabupaten Buleleng adalah masih terbatasnya mata tempel yang berkualitas pada ranting mata tempel yang diperoleh dari BPMT (Blok Penggadaan Mata Tempel) yang diokulasikan pada batang bawah, banyak mata tempel mengalami dormansi terutama yang terletak pada bagian pangkal, karena mata tempel relatif kecil dan bergabus. Sentuhan teknologi seperti aplikasi atonik dapat meningkatkan keberhasilan okulasi jeruk keprok tejakula (Purba, et al., 2018a). Penggunaan pupuk kandang yang ditambahkan fermentor selain mempercepat 
proses dekomposisi, juga meningkatkan kesuburan pupuk kandang tersebut (Purba, et al., 2018b).

Program IbIKK telah memberikan angin segar bagi pengembangan program studi Agroteknologi Fakultas Pertanian Universitas Panji Sakti. Karena itu, pasca pendanaan program IbIKK Bibit Buahbuahan Langka Bali oleh Ditlitabmas Dikti, maka tim pelaksana IbIKK Bibit Buahbuahan Langka Bali akan melanjutkan kegiatan IbIKK sebagai berikut: 1) Melanjutkan produksi bibit dan tabulampot berbagai jenis buah-buah langka Bali, dan tanaman buah lainnya yang diminati konsumen; 2) Memperluas jaringan pemasaran bibit dengan membangun jaringan, meningkatkan promosi melalui penyebaran leaflet, memantapkan kerjasama dengan Kantor Lingkungan Hidup Kabupaten Buleleng, Dinas Pertamanan Kota, SKPD potensial lainnya; 3) Menerima magang/ pratikum/penelitian mahasiswa; 4) Diversifikasi usaha selain pembibitan buah-buahan langka Bali, yaitu: a) jasa layanan konsultasi pertanian dan lingkungan hidup, b) jasa pembuatan dan pemeliharaan taman pada rumah pribadi dan hotel, c) jasa penyewaa tanaman dan pembuatan dekorasi taman sekitar panggung dalam momen tertentu di dalam gedung, 5) Menyusun dan mempublikasikan artikel ilmiah pengabdian kepada masyarakat pada jurnal nasional, 6) IbIKK Bibit Buah-buahan Langka Bali ini akan dikembangkan menjadi unit bisnis pertanian pada Fakultas Pertanian, Universitas Panji Sakti.

Pembelajaran yang didapat selama pelaksanaan IbIKK sampai akhir pendanaan oleh Ditlitabmas Dikti, bahwa IbIKK sebaiknya melakukan diversifikasi usaha, tidak hanya pada aspek pembibitan tanaman buah-buahan langka Bali saja, tetapi tanaman lain yang diminati masyarakat. Agar mampu unggul bersaing dengan penangkar bibit lain yang banyak terdapat di Bali, maka IbIKK harus memrogramkan penggunaan teknologi yang mampu memperbanyak bibit dalam jumlah banyak dan waktu yang singkat seperti teknologi kultur jaringan (Nugroho dan Sugito, 2001; Wardiyati, 1998).

\section{Kesimpulan}

Berdasarkan pelaksanaan program IbIKK Bibit Buah-buahan Langka Bali selama tiga tahun (2014-2016), dapat dirumuskan beberapa simpulan sebagai berikut: 1) Pelaksanaan programkegiatan telah berjalandan realisasi program dan target luaran dapat diwujudkan secara optimal sampai akhir program; 2) Program Kegiatan IbIKK Bibit Buah-buahan Langka Bali selain terkait aspek "bisnis kampus" juga mengemban misi konservasi sumber daya hayati terutama bibit buah-buahan yang sudah mulai langka di Bali; 3) Pengembangan usaha, perlu perencanaan teknis dan biaya pembangunan laboratorium kultur jaringan guna menunjang perbanyakan secara cepat bibit buah langka Bali terutama yang sumber bibitnya sulit didapat, dan agar lebih unggul dalam persaingan dengan penangkar bibit konvensional lainnya;4)Program Kegiatan IbIKK Bibit Buah-buahan Langka Bali telah berjasa mengangkat nama Fakultas Pertanian Universitas Panji Sakti di kancah lokal dan nasional.

\section{Ucapan Terima Kasih}

Terima kasih disampaikan kepada DRPM Ristekdikti dan Universitas Panji Sakti yang telah mendanai kegiatan IbIKK ini.

\section{Daftar Pustaka}

Astirin, O.P. 2000. Permasalahan Pengelolaan Keanekaragaman Hayati di Indonesia. Biodiversitas 1 (1) : 36-40. 
BPLH Bali. 2011. Laporan Status Lingkungan Hidup Daerah Provinsi Bali Tahun 2011. Pemerintah Provinsi Bali, Denpasar.

Dinas Pertanian dan Peternakan Kabupaten Buleleng (2012). Statistika Pertanian dan Peternakan Kabupaten Buleleng Tahun 2012.

Ibrahim, Y. 2003. Studi Kelayakan Bisnis Edisi Revisi. Cetakan 2. Rineka Cipta.Jakarta

Nugroho, A, dan H. Sugito. 2001. Pedoman Pelaksanaan Teknik Kultur Jaringan. Penebar Swadaya. Jakarta.

Peraturan Daerah Provinsi Bali Nomor 16 Tahun 2009 tentang RTRW Provinsi Bali Tahun 2009-2029.

Peraturan Menteri Pertanian No. 48/Permentan/SR.120/8/2012 tentang Produksi, Sertifikasi dan Pengawasan Peredaran Benih Hortikultura.

Purba, J.H., N. Sasmita, L.L. Komara, dan N. Nesimnasi. 2019. Comparison of seed dormancy breaking of Eusideroxylon zwageri from Bali and Kalimantan soaked with sodium nitrophenolate growth regulator. Nusantara Bioscience, Vol. 11(2):146-152
Purba, J.H., P.S.Wahyuni, dan I.G.Suarnaya. 2018a. Pengaruh Posisi Buku Sumber Mata Tempel dan Konsentrasi Atonik terhadap Pertumbuhan Bibit Okulasi Jeruk (Citrus Sp) Varietas Keprok Tejakula. Agro Bali: Agricultural Journal, Vol. 1(1):8-17.

Purba, J.H., P.Parmila, dan K.K.Sari. 2018b. Pengaruh Pupuk Kandang Sapi dan Jarak Tanam terhadap Pertumbuhan dan Hasil Kedelai (Glycine Max L. Merrill) Varietas Edamame. Agro Bali: Agricultural Journal, Vol. 1 (2):69-81

Suhartini. 2009. Peran Konservasi Keanekaragaman Hayati dalam Menunjang Pembangunan Berkelanjutan. DalamProsiding Seminar Nasional Penelitian, Pendidikan dan Penerapan MIPA, Fakultas MIPA, Universitas Negeri Yogyakarta, 16 Mei 2009.

Wardiyati, T. 1998. Kultur Jaringan Tanaman Hortikultura. Lembaga Penerbitan Fakultas Pertanian Universitas Brawijaya. Malang. 